\title{
Temporal variation and detection limit of an estuarine bacterioplankton community analyzed by denaturing gradient gel electrophoresis (DGGE)
}

\author{
Jinjun Kan, Kui Wang, Feng Chen*
}

Center of Marine Biotechnology, University of Maryland Biotechnology Institute, 701 East Pratt Street, Baltimore, Maryland 21202, USA

\begin{abstract}
To understand how the composition of estuarine bacterioplankton changes on a monthly basis, microbial communities in the Baltimore Inner Harbor were investigated using denaturing gradient gel electrophoresis (DGGE) of 16S rRNA gene. As revealed by DGGE fingerprints, the composition of bacterioplankton populations in the harbor varied from month to month, and 3 major seasonal patterns were identified: winter (December and January), spring (February to May) and summer-fall (June to November). Sequencing of DGGE bands showed that Planctomycetes and uncultured $\alpha$-Proteobacteria were detected in all seasons. Roseobacter spp. and Rhodobacter sp. were only present in winter and spring. Marine $\alpha$-Proteobacteria and Cyanobacteria exhibited similar seasonal patterns and appeared to be more dominant from late summer to fall. $\beta$-Proteobacteria were present in most months, but different phylotypes were present from spring to summer-fall. $\gamma$-Proteobacteria and Bacteroidetes were only present in winter and early spring. In addition to DGGE analysis, 48 bacterial isolates from summer and winter were cultured and characterized. Few of these bacterial isolates matched with phylotypes determined by sequencing DGGE bands, which suggested that the density of 'easy-to-culture' bacteria in the natural environment may be too low to be detected by PCR-DGGE. Bacterial seeding experiments showed that detection thresholds for PCRDGGE ranged from $2.5 \times 10^{3}$ to $1 \times 10^{4}$ cells $\mathrm{ml}^{-1}(0.1$ to $0.4 \%$ of total cell counts), depending on the copy number of rRNA operons in the genome of individual species.
\end{abstract}

KEY WORDS: Temporal variation · Bacterioplankton · DGGE detection threshold Resale or republication not permitted without written consent of the publisher

\section{INTRODUCTION}

As an important component of aquatic microbial food webs, bacterioplankton plays a significant role in the global cycle of carbon, nitrogen and other elements. Understanding how the composition of microbial community changes over time and space in a given environment could shed light on the ecological role of microbes in the natural environment. Using molecular tools, many novel microorganisms have been discovered from various environments (Akkermans et al. 1999, Giovannoni \& Rappé 2000). The structure of the bacterial community changes seasonally in aquatic environments (Lee \& Fuhrman 1991, Höfle et al. 1999, Yannarell et al. 2003). For example, an extensive study of lake bacterioplankton showed a distinct seasonal succession and a dramatic drop in richness and abundance in summer (Kent et al. 2004). A recent study in a Californian coastal water body showed that the composition of bacterial populations shifted between months and that temporal patchiness was seen (J. Fuhrman et al. unpubl. data). In estuaries, composition of bacterial populations is due to the mixing of microbial communities from the river, estuary, and coastal ocean (Crump et al. 1999). However, the diversity and population dynamics of bacterioplankton are poorly understood in estuarine ecosystems.

Chesapeake estuary has been shown to be very dynamic in terms of its hydrological conditions (Smith et al. 1992). The Baltimore Inner Harbor lies 14 miles 
$(\sim 22.5 \mathrm{~km})$ from the mouth of the Patapsco River, the fifth largest tributary of the Chesapeake Bay. Baltimore Inner Harbor is part of the mesohaline Patapsco River estuary where freshwater and salt water meet. Dissolved inorganic nitrogen and phosphorus in the surface of Patapsco River estuary exceed 30 and $0.5 \mu \mathrm{M}$, respectively, in the summer period (Sellner et al. 2001). Phytoplankton blooms occur frequently in the Baltimore Inner Harbor from late spring throughout the summer, and the resulting biomass from dinoflagellates supports a large and active microheterotrophic community (Sellner et al. 2001). A tight association between bacteria and phytoplankton was observed during a bloom that occurred in the harbor (Kan \& Chen 2004).

To date, there have been a limited number of studies on the microbial composition in the Chesapeake Bay and its sub-estuaries (Bidle \& Fletcher 1995, Bouvier \& del Giorgio 2002). Banding patterns of 5S rRNA demonstrated that the composition of bacterial communities in the bay varied between summer and winter (Noble et al. 1997). Using fluorescent in situ hybridization (FISH) analysis with taxon-specific probes, it was found that $\gamma$-Proteobacteria and 4 Vibrio spp. strains exhibit strong seasonality in the Choptank River (Heidelberg et al. 2002). However, phylogenetic composition and temporal variations in the bacterioplankton community based on 16S rRNA gene characterization have not yet been explored in the Chesapeake estuary.

Denaturing gradient gel electrophoresis (DGGE) of PCR amplified 16S rRNA genes was first introduced as a quick fingerprint method to study bacterial dynamics at the community level in 1993 (Muyzer et al. 1993). DGGE has been extensively used to study microbial population composition in various environments, including lakes and rivers (Ovreas et al. 1997, Casamayor et al. 2000), coastal waters (Bernard et al. 2000, Crump et al. 2004), polar regions (Murray et al. 1998, Bano \& Hollibaugh 2002, Crump et al. 2003) and extreme environments (Ferris et al. 1996, Sievert et al. 1999, Nakagawa et al. 2004). However, the PCRDGGE method tends to bias towards the predominant groups within a community (von Wintzingerode et al. 1997, Casamyer et al. 2000, Kisand \& Wikner 2003). The detection threshold of DGGE for a specific type of bacterium has been estimated based on mixed bacterial assemblages (Muyzer et al. 1993, Murray et al. 1996) and by double-checking microscopic counts of certain bacterial groups (Casamayor et al. 2000). Using DGGE, it is difficult to detect a bacterial population when it occupies less than 0.5 to $1 \%$ of the total bacterial community. However, more systematic studies need to be done to determine the detection threshold of the PCR-DGGE approach.

The goal of this study was to understand how the composition of an estuarine bacterioplankton com- munity changes over time. We described the monthly variation of bacterial community structure from the Baltimore Inner Harbor using DGGE. In addition, by use of seeding a natural bacterial community with different concentrations of known bacterial isolates, we evaluated the detection threshold of the DGGE method applied in this study. The detection limit of the PCR-DGGE method is affected by the relative abundance of a population as well as by ribosomal RNA (rrn) operon copy numbers.

\section{MATERIALS AND METHODS}

Sample collection and bacterial isolation. Water (5 l) was collected monthly from March 2001 to February 2002 from Pier V, Baltimore Inner Harbor, using acidrinsed carboys; $250 \mathrm{ml}$ of water was filtered immediately through $0.2 \mu \mathrm{m}$ pore-size polycarbonate filters (47 mm diameter, Millipore) and the filters were stored at $-20^{\circ} \mathrm{C}$ for later DNA extraction. Salinity and temperature were recorded on site and salinity was measured with a 300011 refractometer (Sper Scientific).

Bacteria strains from the Inner Harbor were isolated on $1 / 2$ YTSS ( $4 \mathrm{~g}$ yeast extract, $2.5 \mathrm{~g}$ tryptone, $18 \mathrm{~g}$ agar $\mathrm{l}^{-1}$ water) medium plates (Sobecky et al. 1996). The media were adjusted to varying salinities using viral particle-free water. Briefly, 50 and $100 \mu$ l of water were streaked on plates for each month (March 2001 to February 2002). Twenty bacterial colonies from each month were collected according to morphological characteristics including color, size, and shape of colonies. These bacteria colonies were further purified and stored at $-80^{\circ} \mathrm{C}$. In this study, 48 bacterial strains isolated from winter and summer were randomly picked and characterized in terms of 16S rRNA gene sequence.

Enumeration of bacteria. Subsamples of $50 \mathrm{ml}$ water were fixed in $1 \%$ glutaraldehyde for total bacterial counting. Briefly, $1 \mathrm{ml}$ of fixed sample was filtered onto a $0.2 \mu \mathrm{m}$ pore-size $25 \mathrm{~mm}$ black polycarbonate membrane filter (Osmonics). Cells were stained with $2.5 \times$ SYBR Gold solution for $10 \mathrm{~min}$ in the dark as described previously (Chen et al. 2001). Bacterial cells were enumerated under blue excitation $(485 \mathrm{~nm})$ on a Zeiss Axioplan epifluorescence microscope (Zeiss). At least 200 bacterial cells per sample were counted.

Extraction of nucleic acid. Bacterial genomic DNA was obtained from the filter by lysozyme, Proteinase K, and sodium dodecyl sulfate concomitant with phenolchloroform extraction and isopropanol precipitation (Schmidt et al. 1991). For natural microbial assemblages, because the filter membrane was included through the extraction procedure, time allowed for enzyme reactions such as lysozyme and Proteinase K 
was extended overnight to avoid an incomplete reaction. After using a SpeedVac (AES1010, Savant) to dry the pellet, DNA was dissolved in double-distilled water and stored at $4^{\circ} \mathrm{C}$ for further analysis. DNA concentrations were estimated based on $260 \mathrm{~nm}$ absorbance using a SmartSpec TM 3000 (Bio-Rad).

PCR amplification of 16S rRNA genes. PCR amplification was performed in a $50 \mu \mathrm{l}$ volume containing approximately $50 \mathrm{ng}$ of template DNA, $1 \times$ PCR buffer, $1.5 \mathrm{mM} \mathrm{MgCl}_{2}, 0.5 \mathrm{mM}$ (each) primer, $200 \mathrm{mM}$ (each) deoxynucleotide, and $2.5 \mathrm{U}$ Taq DNA polymerase (Promega). PCR cycling was performed with a Peltier Thermal Cycler PTC-200 (MJ Research). For bacterial isolate characterization, PCR primers were 8F (AGAGTTTGATCCTGGCTCA) and 785R (CTACCAGGGTATCTAATCC) (Amann et al. 1995). The temperaturecycling conditions were as follows: $94^{\circ} \mathrm{C}$ for $5 \mathrm{~min}$, 30 cycles at $94^{\circ} \mathrm{C}$ for $0.5 \mathrm{~min}, 55^{\circ} \mathrm{C}$ for $1 \mathrm{~min}$, and $72^{\circ} \mathrm{C}$ for $3 \mathrm{~min}$, followed by $5 \mathrm{~min}$ incubation at $72^{\circ} \mathrm{C}$. PCR primers for DGGE were F1070 (ATGGCTGTCGTCAGCT), which is specific for most Eubacteria and R1392GC (CGCCCGCCGCGCCCCGCGCCCGGCCCGCCGCCCCCGCCCCACGGGCGGTGTGTAC). R1392GC contains a 40 bp GC-rich clamp and is based on a universally conserved region (Ferris et al. 1996). The temperature-cycling conditions were as follows: after pre-incubation at $94^{\circ} \mathrm{C}$ for $5 \mathrm{~min}$, a total of 27 cycles were performed at $94^{\circ} \mathrm{C}$ for $0.5 \mathrm{~min}, T_{A}$ (annealing temperature) for $1 \mathrm{~min}$, and $72^{\circ} \mathrm{C}$ for $3 \mathrm{~min}$. In the first 20 cycles, $T_{A}$ decreased stepwise by $1^{\circ} \mathrm{C}$ every 2 nd cycle, from $65^{\circ} \mathrm{C}$ in the first cycle to $56^{\circ} \mathrm{C}$ in the 20th. In the last 7 cycles, $T_{A}$ was $55^{\circ} \mathrm{C}$. Cycling was followed by 5 min incubation at $72^{\circ} \mathrm{C}$. Agarose gel electrophoresis was used to detect and estimate the concentration of PCR amplicons.

DGGE and banding pattern analysis. DGGE was performed using a Dcode ${ }^{\mathrm{TM}}$ Universal Mutation Detection System (Bio-Rad). Similarly sized PCR products were separated on a $1.5 \mathrm{~mm}$-thick vertical gel containing polyacrylamide (acrylamide:bisacrylamide ratio of 37.5:1) and a linear gradient of the denaturants urea and formamide, which increased from $40 \%$ at the top of the gel to $65 \%$ at the bottom. Similar amounts of PCR products were loaded on the DGGE gel. Electrophoresis was performed at $60^{\circ} \mathrm{C}$ in a $0.5 \times \mathrm{TAE}$ buffer, and $75 \mathrm{~V}$ of electricity were applied to the submerged gel for $16 \mathrm{~h}$. Nucleic acids were visualized by staining with SYBR Gold and photographed (Ovreas et al. 1997). Banding patterns (absence and presence of bands) were analyzed by Quantity One software (Bio-Rad). A pairwise distance matrix was calculated and analyzed with weighted pair group mean average (WPGMA) cluster analysis and presented as a dendrogram.

Sequencing and phylogenetic analysis. PCR products from bacterial isolates were purified using a
Qiaquick PCR purification kit (Qiagen). Purified PCR products were sequenced with primer $8 \mathrm{~F}$ using Bigdyeterminator chemistry by an ABI PRISM310 or 3100 Genetic Analyzer (Applied Biosystems). For the bacterioplankton community, representative DNA bands were excised from the gels, re-amplified, and analyzed with DGGE again. These procedures were repeated 3 times. The DGGE bands were sequenced using the primer F1070.

All sequences were compared with the GenBank database using BLAST, and the closest bacterial strain matches were obtained. Phylogenetic trees were constructed using MacVector 7.2 software package (GCG). Briefly, sequence alignment was performed with the program CLUSTAL W. Evolutionary distances were calculated using the Jukes-Cantor method (Jukes \& Cantor 1969) and a distance tree was constructed using the neighbor-joining algorithm (Saitou \& Nei 1987). Bootstrap values were obtained from the analysis of 1000 re-samplings of the data set.

PCR-DGGE detection limit. Different concentrations $\left(10^{2}\right.$ to $10^{6}$ cells ml $\left.^{-1}\right)$ of 3 bacterial strains (Shewanella sp., Vibrio sp., and Pseudomonas sp.) were added to a natural bacterial community collected from the Inner Harbor. Preliminary results showed that a finer range of concentrations $\left(10^{3}\right.$ to $\left.10^{5} \mathrm{cells} \mathrm{m}^{-1}\right)$ of bacterial isolates was required. Vibrio sp., Pseudomonas sp. and Synechococcus sp. CB0101 were selected because they represented groups with high (9 copies), medium (4 copies), and low (2 copies) rRNA operon copy numbers, respectively. DNA was extracted from the seeded bacterial communities following the protocol applied to natural microbial assemblages, and analyzed by PCR-DGGE following the protocols described above.

Nucleotide sequence accession numbers. Sequences of bacterial isolates and DGGE bands obtained in this study were deposited in the GenBank database under accession numbers AY789535 to AY789582 and AY654428 to AY654452.

\section{RESULTS}

Water temperature of the Baltimore Inner Harbor varied widely across seasons. The lowest water temperature was $6^{\circ} \mathrm{C}$ in the winter while the highest temperature $\left(27^{\circ} \mathrm{C}\right)$ occurred in the summer. Salinity was highest (18 ppt) in the winter and lowest (5 ppt) in the spring. Starting in April, salinity dropped dramatically until May. From June to November salinity was relatively stable (11 to $15 \mathrm{ppt})$. The temperature and salinity recorded in this study were similar to previous and current monthly monitoring data in the Inner Harbor (http://mddnr.chesapeakebay.net/bay_cond/index.cfm). The bacterial density fluctuated from 1.2 to $3.0 \times$ 
$10^{6}$ cells ml $^{-1}$ throughout the year, and did not exhibit an obvious seasonal pattern.

A total of 240 bacterial strains from Inner Harbor were isolated and purified during the sampling year. Characterizing the isolated bacteria from Inner Harbor was not the main focus of this study. Only 48 strains from summer and winter were picked and characterized based on the partial 16S rRNA gene sequence (>500 bp, Table 1), because our DGGE gel showed that bacterial communities were very different between these 2 seasons. Most isolates were similar to known cultivated bacteria in the GenBank. Seventeen out of the 27 winter isolates were most closely affiliated with strains previously isolated from cold environments including polar seas, Arctic sea ice, Antarctica, the Baltic Sea etc. These coldwater isolates were not observed in the summer months (Table 1).

DGGE revealed that the bacterial population structure in the Inner Harbor changed from month to month (Fig. 1). From winter to spring, the band patterns shifted significantly. However, from early summer to fall, the bacterial communities became relatively stable and showed similar band patterns. The monthly samples were grouped into 3 seasonal types: winter (December and January), spring (February to May) and summer-fall (June to November) based on the similarity dendrogram (Fig. 2). The number of DGGE bands in the summer-fall season (avg. $=34.0, \mathrm{n}=6$ ) was higher than that in the winter and spring seasons (avg. $=25.5, \mathrm{n}=6$ ). Twenty-eight bands were selected and excised. To confirm that bands from the same position in different samples represented the same organism, 4 additional bands (Inner Harbor [IH]-6', 11', 21', and $28^{\prime}$ ) were sequenced. These 'replicated' bands were identical to IH-6, 11, 21 and 28, respectively. A total of 25 DGGE phylotypes were identified based on their 16S rRNA gene sequences. Eight sequences were most closely related with $\alpha$-Proteobacteria, 6 with chloroplasts, 4 with $\beta$-Proteobacteria, 3 with Planctomycetes, 2 with $\gamma$-Proteobacteria, 1 with Bacteroidetes and 1 with Cyanobacteria phylotype (Fig. 3). Bands IH$1,3,4$ and 20 could not be re-amplified and therefore no sequences were achieved.

A phylotype of uncultured $\alpha$-Proteobacteria (IH-9) was present all year round, but Roseobacter spp. (IH14 and IH-17) and Rhodobacter sp. (IH-13b) only appeared in winter and spring. Marine $\alpha$-Proteobacterium ( $\mathrm{IH}-24)$ was restricted to summer-fall and winter. Phylotypes of $\beta$-Proteobacteria shifted between winter-spring and summer-fall, and changed from Aquaspirllum sp. and Variovorax sp. (IH-15 and IH-16; winter-spring) to Hydrogenophaga flava and Alcaligenes sp. (IH-19 and IH-21; summer-fall). $\gamma$-Proteobacteria (IH-12 and IH-13a) were only present in winter and early spring. Cyanobacteria (Synecho- coccus sp.) were commonly found in the summer-fall season but disappeared in winter and spring. Similar seasonal patterns were found in some plastids (IH-6, $\mathrm{IH}-7$ and IH-8). However, in winter, different plastids (IH-5 and $\mathrm{IH}-10)$ became prevalent. Bacteroidetes (IH-28) and Planctomycetes (IH-27) were relatively dominant in the spring and early summer, but absent in other seasons (Figs. $1 \& 3$ ).

Because few of the characterized heterotrophic bacteria isolates were seen in the DGGE phylotypes, additional experiments were conducted to understand the discrepancy between culture-dependent and molecular approaches. Different concentrations of cultivated bacterial cells were added to a natural microbial assemblage in order to estimate the detection threshold of DGGE. DNA extraction efficiency was tested. With the increase of cells amended, DNA concentration increased and showed a close relationship with cell densities (Fig. 4). The corresponding bands for Vibrio sp. and Shewanella sp. could be conveniently detected when cell densities were above $5 \times 10^{3}$ cells $\mathrm{ml}^{-1}$, whereas Pseudomonas sp. presented weak bands even when the density reached $1 \times 10^{4}$ cells ml$^{-1}$ (Fig. 5). Furthermore, when the concentration of seeded bacteria increased to $10^{6} \mathrm{cells} \mathrm{ml}^{-1}$, most DGGE phylotypes from natural water became undetectable on the gel (Fig. 5, Lane 8).

The detection threshold was further analyzed by adding a more stringent range of cells (Fig. 6a). At a concentration of $2.5 \times 10^{3}$ cells ml $^{-1}$, the band corresponding to Vibrio sp. with high gene copy numbers could be detected. However, the band representing Pseudomonas sp. could not be seen until cell density reached $1 \times 10^{4}$ cells ml $^{-1}$ (Fig. 6b). With an average bacterial concentration of $2.43 \times 10^{6}$ cells ml $^{-1}$ in the water, the detection threshold for Vibrio sp. and Pseudomonas sp. corresponded to 0.1 and $0.4 \%$ of total bacterial cell counts, respectively. The band corresponding to the introduced Synechococcus sp. strain ran at the same position as a band from the natural assemblage. Sequencing of the bands showed that they were identical phylotypes. Therefore, the detection limit for Synechococcus sp. could not be properly evaluated.

\section{DISCUSSION}

Based on a single rich medium, our cultured bacterial isolates provided only a 'snapshot' of 'easy-to-culture' bacteria of the whole community. It was not our intention in this study to conduct a thorough survey of Inner Harbor bacterial isolates. The region of the 16S rRNA gene used for characterizing bacterial isolates $(8 \mathrm{~F}$ to 785R) did not overlap with the region flanked by 


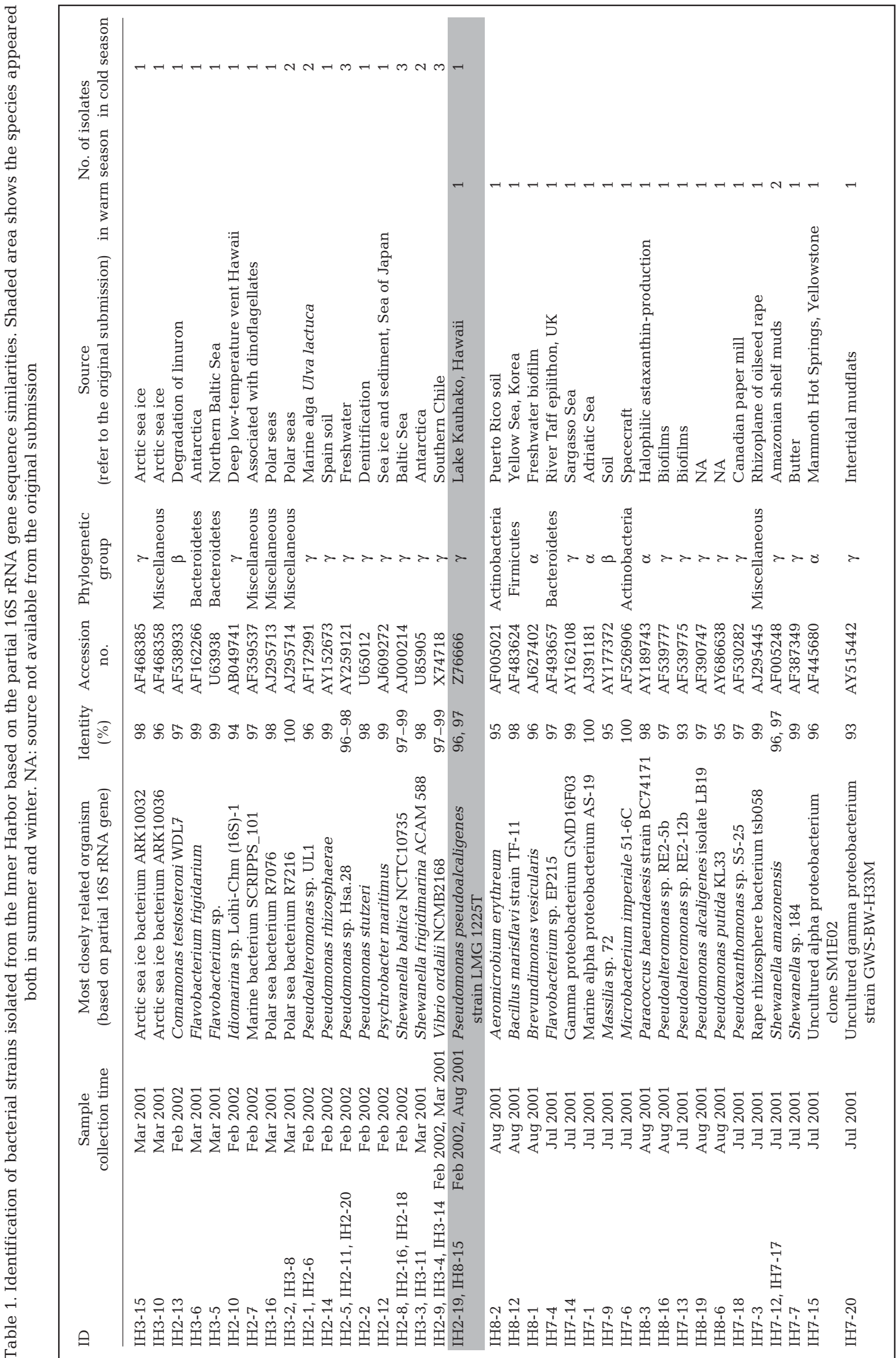




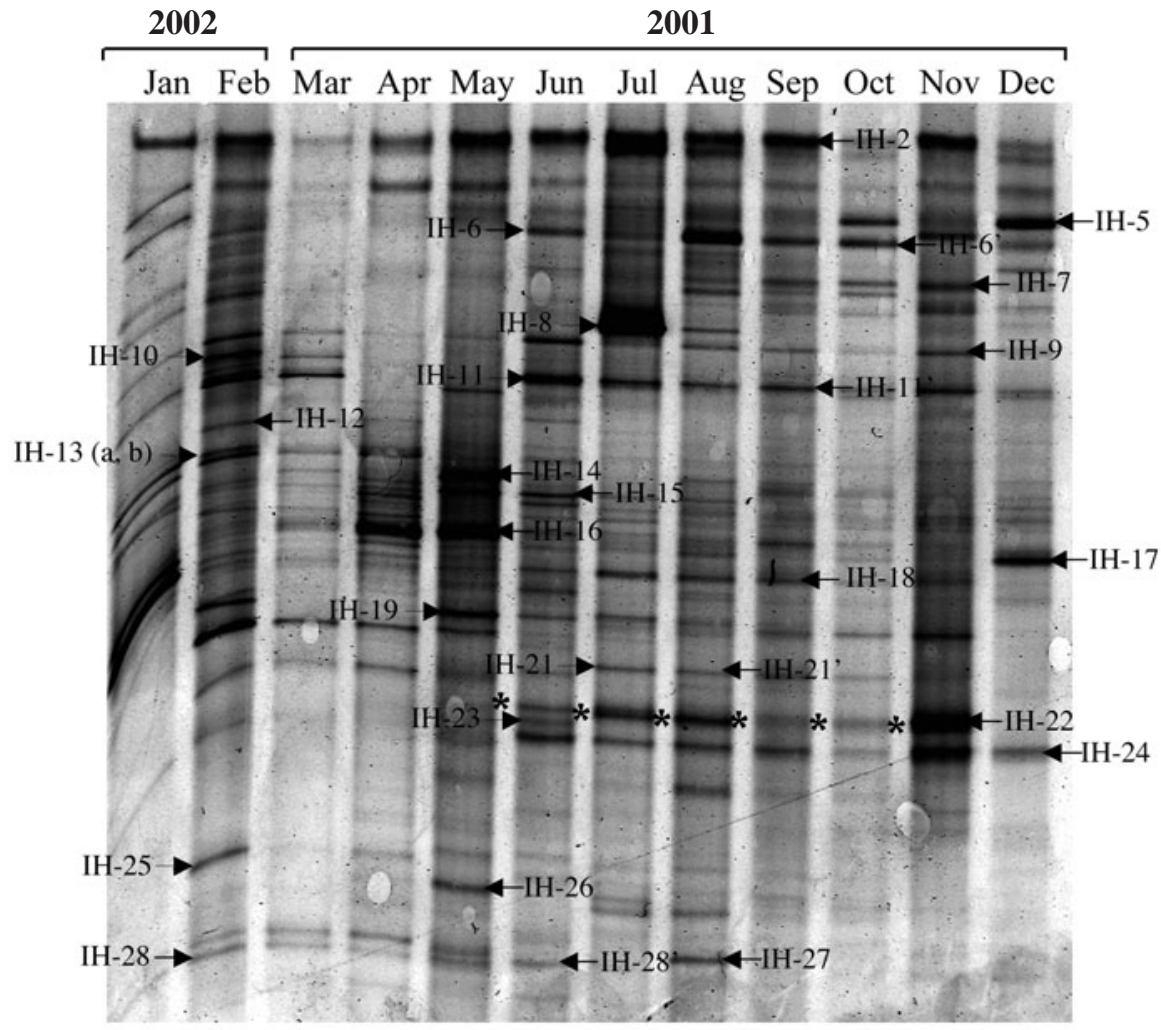

Fig. 1. Monthly patterns of Harbor bacterial composition revealed by DGGE Numbered bands are those excised and sequenced; Synechococcus bands labeled with *. From July to November, Synechococcus cell counts were $8.1 \times$ $10^{4}, 5.2 \times 10^{4}, 7.4 \times 10^{4}, 2.0 \times 10^{4}$, and $1.1 \times 10^{4}$ cells $\mathrm{ml}^{-1}$, respectively (Wang \& Chen 2004)

DGGE primers (1070F to $1392 \mathrm{R}$ ). It would be ideal to compare the partial 16S rRNA sequence of bacterial isolates and DGGE bands at the same region. We tested the 8 closest hits of our sequences and BLAST using a short (500 bp) and long ( 1400 bp) fragment of 16S rRNA gene sequences. Six of the 8 sequences (AF468358, AF538933, AJ295714, AY162673, Z76666, and AF483624) showed similar BLAST outcomes at the strain or species level. Therefore, the comparison between bacterial isolates and DGGE phylotypes should not have been significantly affected by the nonoverlapped primers.

It was intriguing to learn that few of the 48 characterized bacterial isolates matched with phylotypes from DGGE band sequences. Is the cell density of isolated bacteria in natural waters too low to be detected by PCR-DGGE? If so, what is the detection threshold of PCR-DGGE for estuarine bacterioplankton? Muyzer et al. (1993) and Murray et al. (1996) reported that PCRDGGE is sensitive enough to detect 1 to $2 \%$ of bacterial populations in the mixed assemblage of selected bacterial strains. The introduction of serially diluted bacteria into a natural community allowed us to get a direct estimate of the detection limit based on cell number. Our experiments with seeded bacteria suggested that the detection threshold varied with different bacterial species. For example, Vibrio sp. could be detected at $2.5 \times 10^{3}$ cells $\mathrm{ml}^{-1}$ (Fig. 6), which corresponded to $\sim 0.1 \%$ of the total bacterial population $\left(2.1 \times 10^{6}\right.$ cells $\mathrm{ml}^{-1}$ ). However, Pseudomonas sp. was not detectable until cell density reached $1 \times 10^{4}$ cells ml ${ }^{-1}$ (Figs. $5 \& 6$ ) . Interestingly, the Synechococcus sp. bands detected (Fig. 1) corresponded to samples where Synechococcus counts were over $1.1 \times 10^{4}$ cells ml ${ }^{-1}$ (Wang \& Chen 2004). No Synechococcus sp. DGGE bands were detectable when Synechococcus sp. cell densities were low. This result also supports a previous study on the detection limit of Synechococcus sp. in Lake Cisó and Lake Vilar, NE Spain (Casamayor et al. 2000).

It is known that many factors (DNA extraction, primer selection, PCR cycles, gene copy number, etc.) can influence the outcome of PCR, particularly when applied to environmental samples (e.g. Farrelly et al. 1995, Suzuki \& Giovannoni 1996, von Wintzingerode et al. 1997, Crosby \& Criddle 2003). We characterized the total bacterial community in the Inner Harbor, without pre-filtration to remove phytoplankton cells. Six plastid sequences related to eukaryotic algae were identified in the DGGE fingerprints. The presence of algal DNA will affect the DGGE patterns of the bacterial community, but will also provide

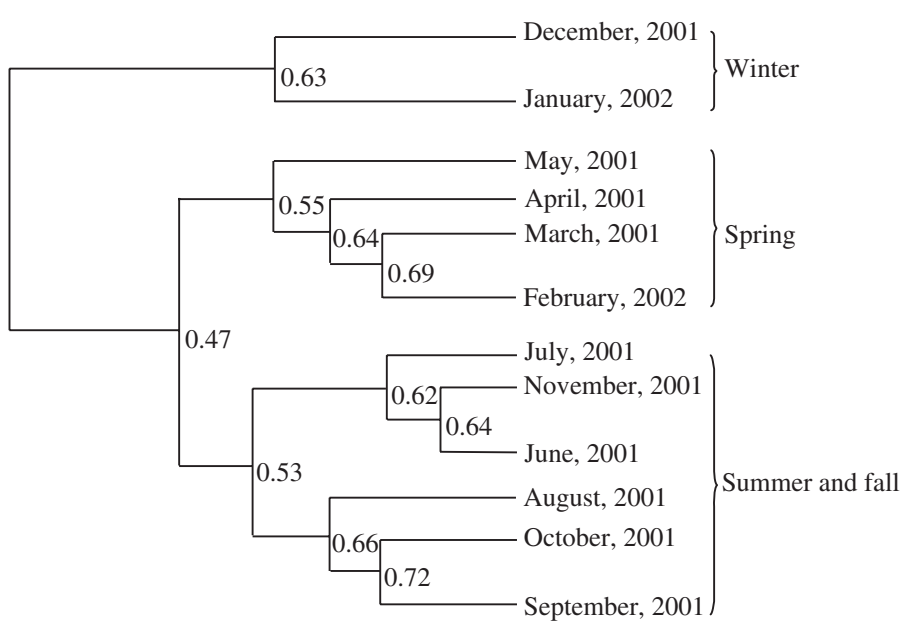

Fig. 2. Dendrogram based on similarity matrix of bacterioplankton DGGE fingerprint banding patterns from 12 monthly samples. Similarities (as proportions of 1) between band patterns are indicated at branch divisions 


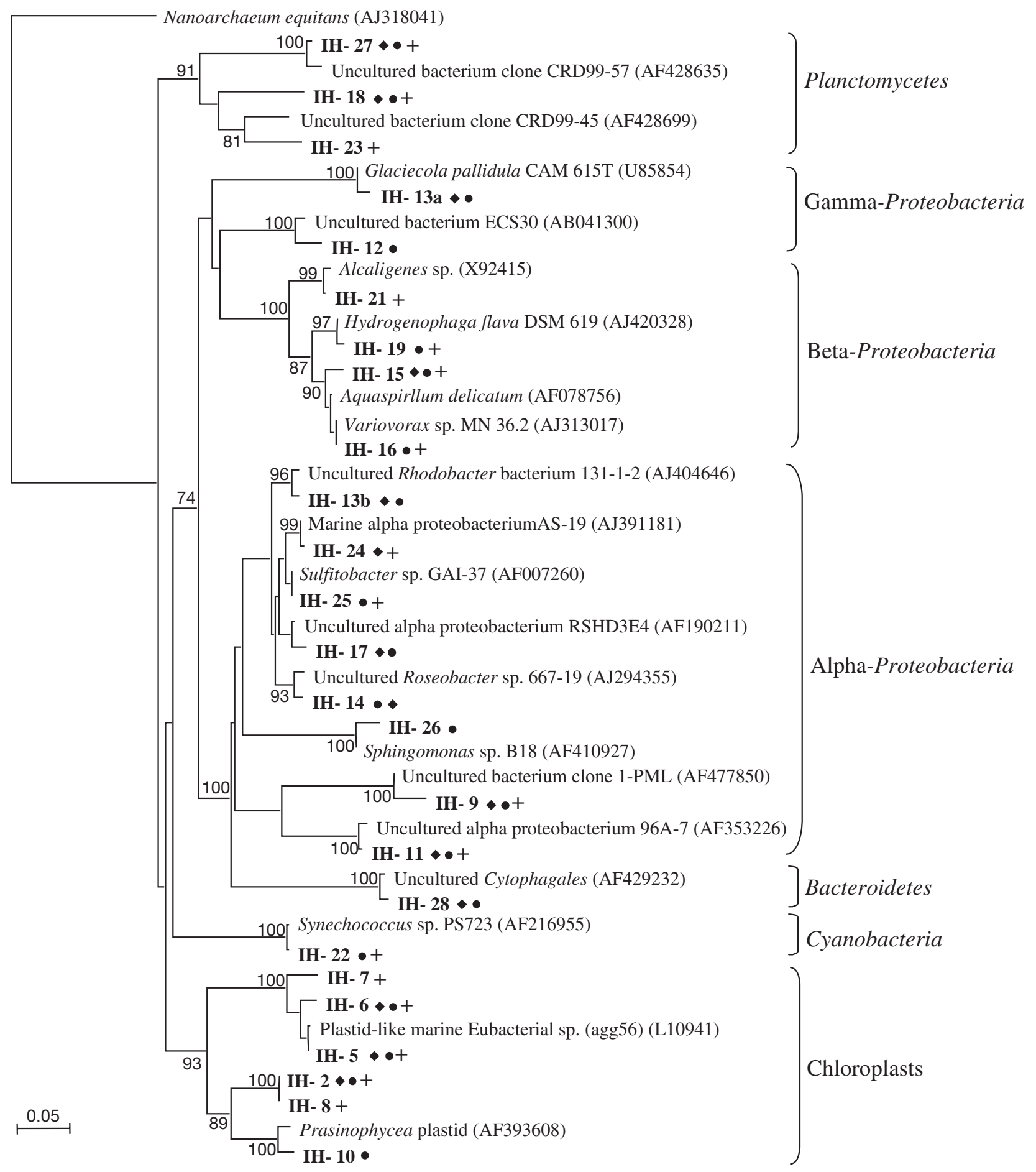

Fig. 3. Phylogenetic affiliations of representative 16S rRNA gene sequences from excised DGGE bands. Sequences from this study in bold. $\bullet$ DGGE band present in winter; $\bullet$ : DGGE band present in spring; +: DGGE band present in summer-fall. Nanoarchaeum equitans was used as an outgroup. Scale bar $=0.05$ substitutions per site

valuable information on the population dynamics of dominant phytoplankton. The primers used in this study yielded $320 \mathrm{bp}$ amplicons, which overlapped with the V8 variable region in the 16S rRNA gene. Recently, dif- ferent sets of DGGE primers were evaluated based on the bacterial community in the maize rhizosphere or rumen digesta of sheep. Universal primers based on region V3 of 16S rRNA were recommended for shorter frag- 


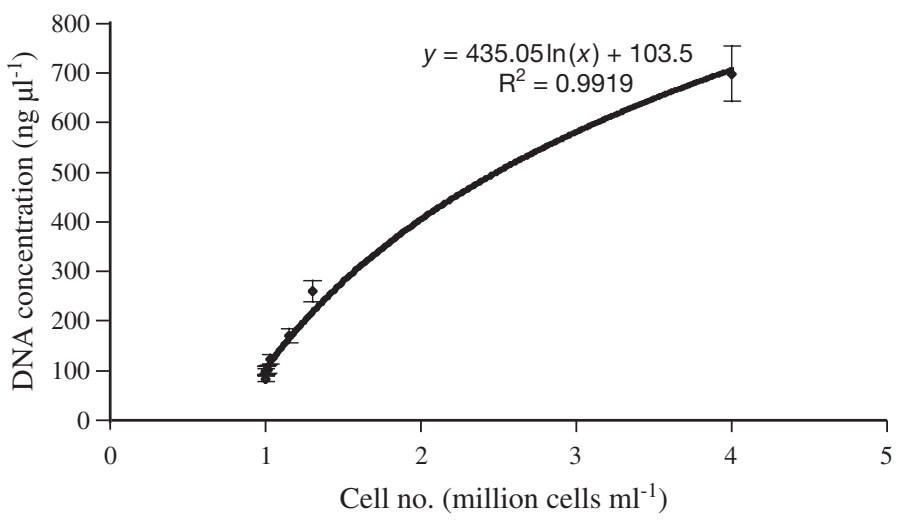

Fig. 4. DNA extraction efficiency of seeding experiment. Equation shows relationship between DNA concentration and total cell numbers

ments, while regions V3-V5 and V6-V8 were suggested for longer fragments ( $Y u$ \& Morrison 2004). However, to our knowledge, those DGGE primers have not been compared systematically for planktonic bacterial communities. This is an important issue that warrants future study. In a recent study in the Chesapeake Bay, our DGGE band sequences matched well with clone library sequences (16S-ITS-23S region) (authors' unpubl. data), which suggested that the major bacterioplankton populations were not distorted by the DGGE primers we used.
It is worth pointing out that the detection limit of PCR-DGGE in our study appeared to be affected by gene copy number. Ribosomal RNA gene-based molecular techniques (i.e. PCR-DGGE, LH-PCR, ARISA, TRFLP etc.) present a quantitative bias towards organisms with higher gene copy numbers (Crosby \& Criddle 2003). At the time, the Ribosomal RNA Operon Copy Number Database (rrndb) (Klappenbach et al. 2001) contained 502 entries, with 259 genome sizes and rRNA operon copy numbers available. There was no obvious relationship between rRNA operon copy number and genome size $\left(r^{2}=0.18\right)$ (Fig. 7). We chose several bacterial strains for the detection threshold study, selected to reflect different rRNA gene multiplicity. Genomes of Vibrio spp. and Shewanella spp. typically contain 9 copies of the rRNA operon; Pseudomonas spp. has on average 4 copies, while Synechococcus spp. contains 2 copies (Fig. 7). Our results indicated that the detection threshold for PCRDGGE was affected by the gene copy number of the 16S rRNA operon. Bacterial groups in natural environments with low rRNA operon copy numbers may need to reach higher cell densities to be detectable by PCRDGGE.

The detection threshold of DGGE provides a possible explanation as to why most cultured bacteria could not be detected by DGGE. It is likely that the concentration of most bacteria grown on enriched media was

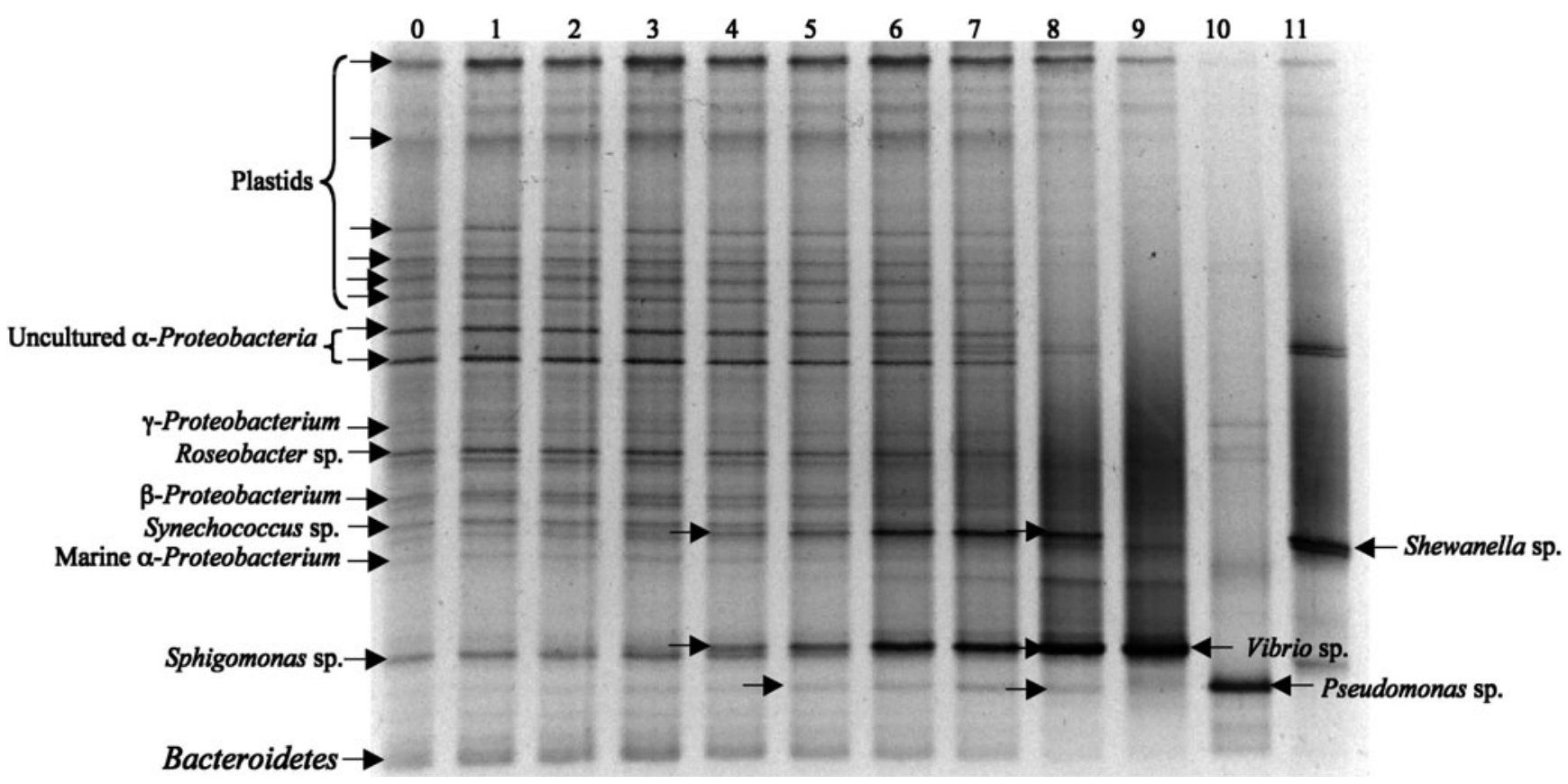

Fig. 5. DGGE detection threshold measured by seeding a natural microbial community with different concentrations of 3 bacterial strains (Vibrio sp., Pseudomonas sp., and Shewanella sp.). Lanes 0 to 8 : negative control $\left(0\right.$ cells), 100, 500, $1 \times 10^{3}, 5 \times$ $10^{3}, 1 \times 10^{4}, 5 \times 10^{4}, 1 \times 10^{5}$ and $1 \times 10^{6}$ cells ml $^{-1}$ added, respectively. Lanes 9 to 11: DGGE fingerprints for pure cultures of Vibrio sp., Pseudomonas sp. and Shewanella sp., respectively. Closest phylogenetic affiliations of band sequences shown on left 


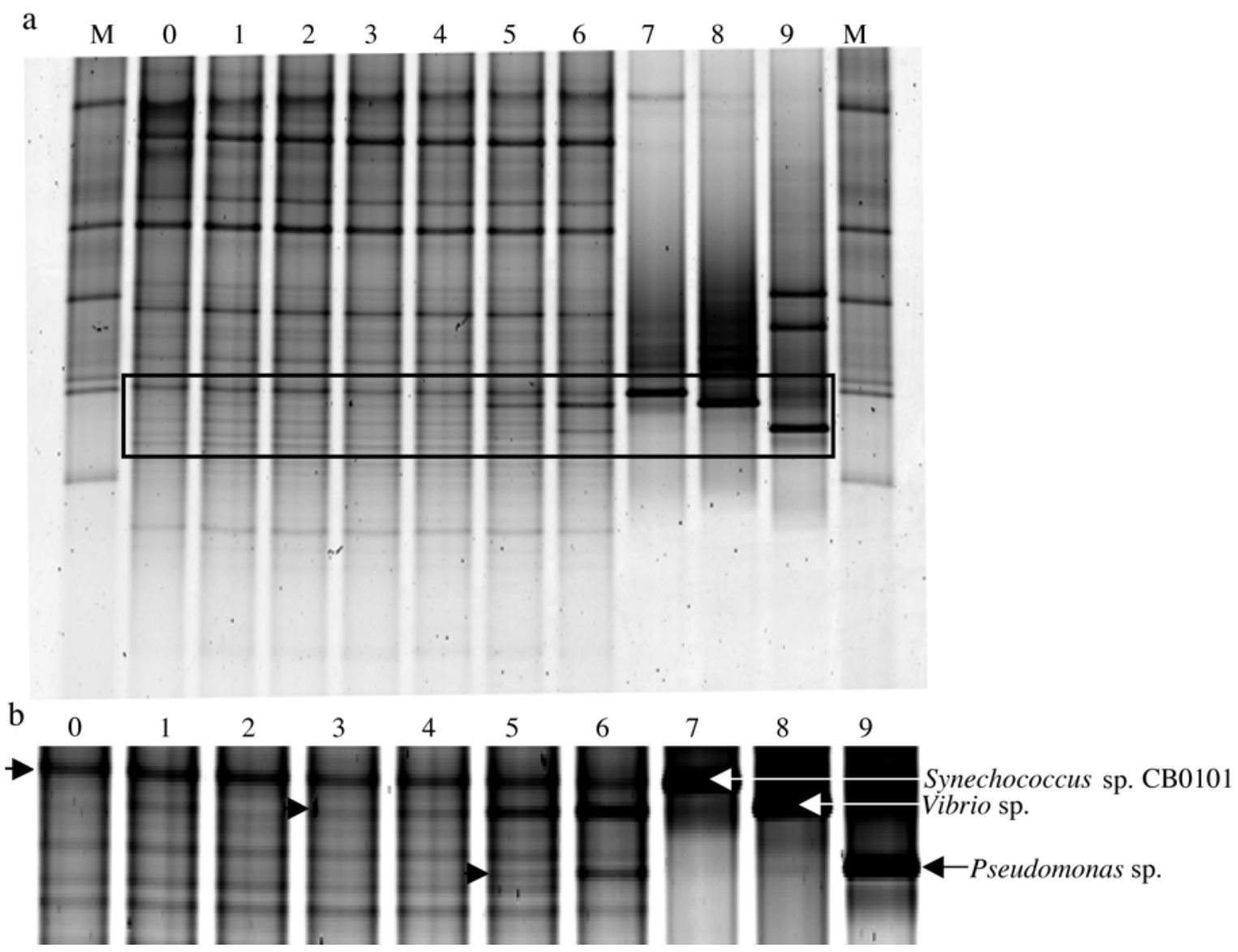

Fig. 6. DGGE detection threshold measured by seeding a natural microbial community with finer range concentrations of 3 bacterial strains (Synechococcus sp. CB0101, Vibrio sp., and Pseudomonas sp.). (a) Lanes 0 to 6: negative control (0 cells), $1 \times 10^{3}$, $2 \times 10^{3}, 2.5 \times 10^{3}, 5 \times 10^{3}, 1 \times 10^{4}$, and $1 \times 10^{5}$ cells ml $^{-1}$ added, respectively. Lanes 7 to 9: DGGE fingerprints for pure cultures of Synechococcus sp. CB0101, Vibrio sp., and Pseudomonas sp., respectively. M: marker consisting of DGGE bands identified as chloroplast, uncultured $\alpha$-Proteobacterium, Roseobacter sp., $\beta$-Proteobacterium, Synechococcus sp. and Cytophaga sp.

(b) Enhanced view of subsection highlighted in (a)

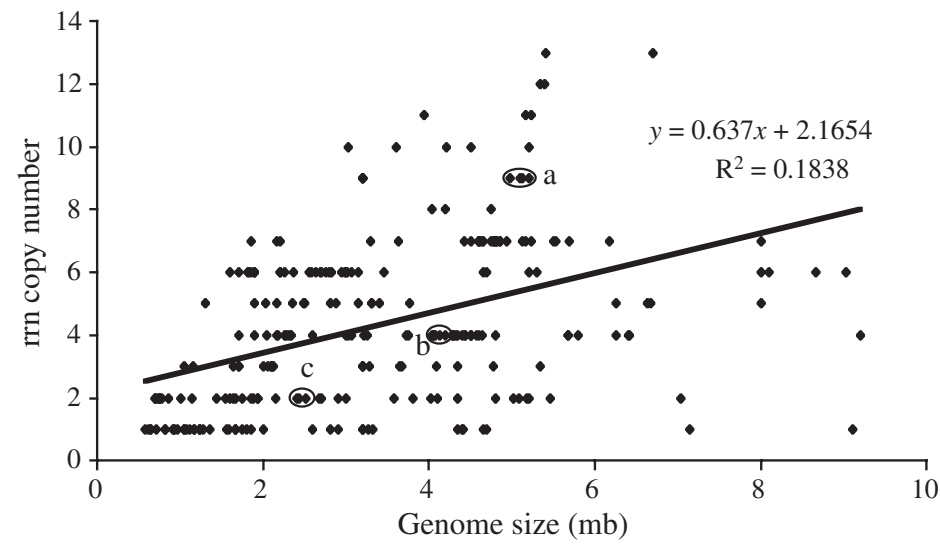

Fig. 7. Distribution of rrn operon copy numbers vs. genome size of rrndb bacterial entries. a, b, and c represented closest relatives of bacterial isolates added in seeding experiments; a: Vibrio spp. and Shewanella spp.; b: Pseudomonas spp.; c: Synechococcus spp. At this time, rrndb comprises 259 entries with both rrn operon copy number and genome size available low in the natural samples. On average, the total colony counts on plates were 6450 cells $\mathrm{ml}^{-1}(\mathrm{n}=8)$. Assuming that the colonies on 1 plate were equally derived from 10 different bacterial species, the abundance of each species accounted for $0.265 \%$ of the total cell density (avg. $2.43 \times 10^{6}$ cells ml ${ }^{-1}$ ). Therefore, their concentrations were lower than the detection limit and they were absent from the DGGE gel. A limited number of bands indicated that DGGE is biased toward abundant groups in the community and underestimates actual bacterial diversity in the samples.

Our results demonstrated that bacterial community structure in the estuarine ecosystem is variable between months, but that a seasonal pattern could be identified. Overall, bacterial communities in the summer-fall season were more similar to each other, whereas winter communities appeared to be distinct from spring, summer and fall. Two populations that corresponded to phylotypes of Cyanobacteria (Syne- 
chococcus sp.) and marine $\alpha$-Proteobacterium exhibited a similar seasonal pattern in the Inner Harbor. Occurrence of the Synechococcus sp. phylotype in the DGGE analysis supported the seasonal distribution of Synechococcus sp. cell densities in the harbor (Wang \& Chen 2004). The abundance of Synechococcus reached $8.14 \pm 0.98 \times 10^{4}$ cells ml $^{-1}$ in summer (July), and decreased to $2.57 \pm 0.53 \times 10^{2}$ cells ml $^{-1}$ in winter (February). The marine $\alpha$-Proteobacterium phylotype (IH-24) followed a seasonal pattern similar to that of the Synechococcus sp. Marine $\alpha$-Proteobacteria have been found in a number of marine environments (Gonzalez \& Moran 1997, Suzuki et al. 1997). This group of bacteria is numerically dominant $(28 \%)$ in coastal waters, but not detectable in low salinity $(<5 \mathrm{ppt})$ or freshwater (Gonzalez \& Moran 1997). In the Baltimore Inner Harbor, no marine $\alpha$-Proteobacterium were found in April and May when salinity was at its lowest ( 5 ppt). However, marine $\alpha$-Proteobacteria were also not detected in other months (January to March) when salinity was above $15 \mathrm{ppt}$, which suggested that this group may be sensitive not only to salinity, but also to water temperature.

As $\beta$-Proteobacteria are dominant in freshwater and have never been found in marine water (Methe et al. 1998, Glöckner et al. 1999), it is believed that this group advected into the estuary from the Patapsco River. One Bacteroidetes phylotype (IH-28) with high $\mathrm{G}+\mathrm{C}$ content was detected from January to June, but was not detected in other months. The Bacteroidetes group is abundant in marine systems (Glöckner et al. 1999) including Delaware estuarine and coastal waters (Cottrell \& Kirchman 2000, Kirchman et al. 2003). Because these species are known to be involved in the degradation of complex macromolecules (Shewan \& McMeekin 1983), they adapt well to water with high particle loads (Cottrell \& Kirchman 2000). In spring, terrestrial run-off from the Patapsco River provides the largest load of nutrients and particles to the Inner Harbor (Boesch et al. 2001, Sellner et al. 2001), which may offer suitable environmental niches to this group.

Chesapeake estuarine bacterioplankton are composed of mixed populations from both freshwater and marine origin, and the balance of these populations may be interpreted by seasonal variability. It has been reported that bacterioplankton communities in freshwater differ from those in marine communities (e.g. Gonzalez \& Moran 1997, Methe et al. 1998, Glöckner et al. 1999, Cottrell \& Kirchman 2000, Zwart et al. 2002). In estuaries, dominating bacterial groups shift along the salinity gradient from $\alpha$ - and $\beta$-Proteobacteria, Gram-positive bacteria, and Verrucomicrobia to $\alpha$ - and $\gamma$-Proteobacteria (Crump et al. 1999). Increasing precipitation that started from late March in the Inner
Harbor (www.atmos.umd.edu/ climate/) resulted in a significant drop in salinity in April. Thereafter, $\beta$ Proteobacteria (IH-15, IH-16, and IH-19) dominated spring bacterial communities. It is likely that river run-off brings more freshwater populations into the harbor in spring. In contrast, salinities in winter and summer-fall were relatively stable but temperatures changed remarkably, which suggested that the shift in bacterial composition between summer and winter was possibly related to temperature fluctuations rather than to salinity. To understand the interaction between community shifts and environmental factors, we are currently conducting an inter-annual survey to investigate the spatial and temporal variations of Chesapeake Bay bacterioplankton.

Acknowledgements. We thank A. Haniff for his help collecting water samples. We are especially grateful to B. Crump and $\mathrm{M}$. Anderson for valuable discussion and comments on the manuscript. This work was supported by National Science Foundation Microbial Observatories Programs (MCB-0132070 and MCB-0238515), and represents contribution no. 05-133 from the Center of Marine Biotechnology, University of Maryland Biotechnology Institute.

\section{LITERATURE CITED}

Akkermans ADL, van Elsas JD, de Bruijn FJ (1999) Molecular microbial ecology manual. Kluwer Academic Publishers, Dordrecht

Amann RI, Ludwig W, Schleifer K (1995) Phylogenetic identification and in situ detection of individual microbial cells without cultivation. Microbiol Rev 59:143-169

Bano N, Hollibaugh JT (2002) Phylogenetic composition of bacterioplankton assemblages from the Arctic Ocean. Appl Environ Microbiol 68:505-518

Bernard L, Schaefer H, Joux F, Courties C, Muyzer G, Lebaron P (2000) Genetic diversity of total, active and culturable marine bacteria in costal seawater. Aquat Microb Ecol 23:1-11

Bidle KD, Fletcher M (1995) Comparison of free-living and particle-associated bacterial communities in the Chesapeake Bay by stable low-molecular-weight RNA analysis. Appl Environ Microbiol 61:944-952

Boesch DF, Brinsfield RB, Magnien RE (2001) Chesapeake Bay eutrophication: scientific understanding, ecosystem restoration, and challenges for agriculture. J Environ Qual 30:303-320

Bouvier TC, del Giorgio PA (2002) Compositional changes in free-living bacterial communities along a salinity gradient in two temperate estuaries. Limnol Oceanogr 47:453-470

Casamayor EO, Schafer H, Baneras L, Pedros-Alio C, Muyzer G (2000) Identification of and spatio-temporal differences between microbial assemblages from two neighboring sulfurous lakes: comparison by microscopy and denaturing gradient gel electrophoresis. Appl Environ Microbiol 66:499-508

Chen F, Lu J, Binder BJ, Liu Y, Hodson RE (2001) Application of digital image analysis and flow cytometry to enumerate marine viruses stained with SYBR Gold. Appl Environ Microbiol 67:539-545

Cottrell MT, Kirchman DL (2000) Community composition of marine bacterioplankton determined by $16 \mathrm{~S}$ rRNA gene 
clone libraries and fluorescence in situ hybridization. Appl Environ Microbiol 66:5116-5122

Crosby LD, Criddle CS (2003) Understanding bias in microbial community analysis techniques due to rrn operon copy number heterogeneity. Biotechniques 34:790-802

Crump BC, Armbrust EV, Baross JA (1999) Phylogenetic analysis of particle-attached and free-living bacterial communities in the Columbia River, its estuary, and the adjacent coastal ocean. Appl Environ Microbiol 65:3192-3204

Crump BC, Kling GW, Bahr M, Hobbie JE (2003) Bacterioplankton community shifts in an Arctic lake correlate with seasonal changes in organic matter source. Appl Environ Microbiol 69:2253-2268

Crump BC, Hopkinson CS, Sogin ML, Hobbie JE (2004) Microbial biogeography along an estuarine salinity gradient: combined influences of bacterial growth and residence time. Appl Environ Microbiol 70:1494-1505

Farrelly V, Rainey FA, Stachebrandt E (1995) Effects of genome size and rrn gene copy number on PCR amplification of 16S rRNA genes from a mixture of bacterial species. Appl Environ Microbiol 61:2798-2801

Ferris MJ, Muyzer G, Ward DM (1996) Denaturing Gradient Gel Electrophoresis profiles of 16S rRNA-defined populations inhabiting a hot spring microbial mat community. Appl Environ Microbiol 62:340-346

Giovannoni SJ, Rappé MS (2000) Evolution, diversity, and molecularecology of marine prokaryotes. In: Kirchman DL (ed) Microbial ecology of the oceans. Wiley-Liss, New York, p 47-84

Glöckner FO, Fuchs BM, Amann R (1999) Bacterioplankton compositions of lakes and oceans: a first comparison based on fluorescence in situ hybridization. Appl Environ Microbiol 65:3721-3726

Gonzalez JM, Moran MA (1997) Numerical dominance of a group of marine bacteria in the $\alpha$-subclass of the class Proteobacteria in coastal seawater. Appl Environ Microbiol 63:4237-4242

Heidelberg JF, Heidelberg KB, Colwell RR (2002) Seasonality of Chesapeake Bay bacterioplankton species. Appl Environ Microbiol 68:5488-5497

Höfle MG, Haas H, Dominik K (1999) Seasonal dynamics of bacterioplankton community structure in a eutrophic lake as determined by 5S rRNA analysis. Appl Environ Microbiol 65:3164-3174

Jukes TH, Cantor CR (1969) Evolution of protein molecules. In: Munro HN (ed) Mammalian protein metabolism. Academic Press, New York, p 21-132

Kan J, Chen F (2004) Co-monitoring bacterial and dinoflagellates communities by denaturing gradient gel electrophoresis (DGGE) and SSU rDNA sequencing during a dinoflagellate bloom. Acta Oceanol Sin 23:483-492

Kent AD, Jones SE, Yannarell AC, Graham JM, Lauster GH, Kratz TK, Triplett EW (2004) Annual patterns in bacterioplankton community variability in a humic lake. Microb Ecol 48:550-560

Kirchman DL, Yu L, Cottrell MT (2003) Diversity and abundance of uncultured Cytophaga-like bacteria in the Delaware estuary. Appl Environ Microbiol 69:6587-6596

Kisand V, Wikner J (2003) Combining culture-dependent and -independent methodologies for estimation of richness of estuarine bacterioplankton consuming riverine dissolved organic matter. Appl Environ Microbiol 69: 3607-3616

Klappenbach JA, Saxman PR, Cole JR, Schmidt TM (2001) rrndb: the ribosomal RNA operon copy number database. Nucleic Acids Res 29:181-184

Lee S, Fuhrman JA (1991) Spatial and temporal variation of natural bacterioplankton assemblages studied by total genomic DNA cross-hybridization. Limnol Oceanogr 36: $1277-1287$

Methe BA, Hiorns WD, Zehr JP (1998) Contrasts between marine and fresh water bacterial community composition: analyses of communities in Lake George and six other Adirondack lakes. Limnol Oceanogr 43:368-374

Murray AE, Hollibaugh JT, Orrego C (1996) Phylogenetic compositions of bacterioplankton from two California estuaries compared by denaturing gradient gel electrophoresis of 16S rDNA fragments. Appl Environ Microbiol 62:2676 - 2680

Murray AE, Preston CM, Massana R, Taylor LT, Blakis A, Wu K, DeLong EF (1998) Seasonal and spatial variability of bacterial and archaeal assemblages in the coastal waters near Anvers Island, Antarctica. Appl Environ Microbiol 64:2585-2595

Muyzer G, de Waal E, Uitterlinden A (1993) Profiling of complex microbial populations by denaturing gradient gel electrophoresis analysis of polymerase chain reactionamplified genes coding for 16S rRNA. Appl Environ Microbiol 59:695-700

Nakagawa T, Ishibashi J, Maruyama A, Yamanaka T, Morimoto Y, Kimura H, Urabe T, Fukui M (2004) Analysis of dissimilatory sulfite reductase and 16S rRNA gene fragments from deep-sea hydrothermal sites of the Suiyo Seamount, Izu-Boniin Arc, Western Pacific. Appl Environ Microbiol 70:393-403

Noble PA, Bidle KD, Fletcher M (1997) Natural microbial community compositions compared by a back-propagating neural network and cluster analysis of 5S rRNA. Appl Environ Microbiol 63:1762-1770

Ovreas L, Forney L, Daae FL, Torsvik V (1997) Distribution of bacterioplankton in meromictic Lake Saelenvannet, as determined by denaturing gradient gel electrophoresis of PCR-amplified gene fragments coding for 16S rRNA. Appl Environ Microbiol 63:3367-3373

Saitou N, Nei M (1987) The neighbor-joining method: a new method for reconstructing phylogenetic trees. Mol Biol Evol 4:406-425

Schmidt TM, Delong EF, Pace NR (1991) Analysis of a marine picoplankton community by $16 \mathrm{~S}$ rRNA gene cloning and sequencing. J Bacteriol 173:4371-4378

Sellner KG, Sellner SG, Lacouture RV, Magnien RE (2001) Excessive nutrients select for dinoflagellates in the stratified Patapsco River estuary: Margalef reigns. Mar Eco Prog Ser 220:93-102

Shewan JM, McMeekin TA (1983) Taxonomy (and ecology) of Flavobacterium and related genera. Annu Rev Microbiol 37:233-252

Sievert SM, Brinkhoff T, Muyzer G, Ziebis W, Kuever J (1999) Spatial heterogeneity of bacterial populations along an environmental gradient at a shallow submarine hydrothermal vent near Milos Island (Greece). Appl Environ Microbiol 65:3834-3842

Smith DE, Leffler M, Mackiernan G (1992) Oxygen dynamics in the Chesapeake Bay: a synthesis of recent research. Maryland Sea Grant, College Park, MD

Sobecky PA, Schell MA, Moran MA, Hodson RE (1996) Impact of a genetically engineered bacterium with enhanced alkaline phosphatase activity on marine phytoplankton communities. Appl Environ Microbiol 62:6-12

Suzuki MT, Giovannoni SJ (1996) Bias caused by template annealing in the amplification of mixtures of 16S rRNA genes by PCR. Appl Environ Microbiol 62:625-630

Suzuki MT, Rappé MS, Haimberger ZW, Winfield H, Adair N, Strobel J, Giovannoni SJ (1997) Bacterial diversity among 
small-subunit rRNA gene clones and cellular isolates from the same seawater sample. Appl Environ Microbiol 63: 983-989

von Wintzingerode F, Gobel UB, Stachebrandt E (1997) Determination of microbial diversity in environmental samples: pitfalls of PCR-based rRNA analysis. FEMS Microbiol Rev 21:213-229

Wang K, Chen F (2004) Genetic diversity and population dynamics of cyanophage communities in the Chesapeake Bay. Aquat Microb Ecol 34:105-116

Yannarell AC, Kent AD, Lauster GH, Kratz TK, Triplett EW

Editorial responsibility: Jed Fuhrman,

Los Angeles, California, USA
(2003) Temporal patterns in bacterial communities in three temperate lakes of different trophic status. Microb Ecol 46:391-405

Yu Z, Morrison M (2004) Comparisons of different hypervariable regions of rrs genes for use in fingerprinting of microbial communities by PCR-denaturing gradient gel electrophoresis. Appl Environ Microbiol 70:4800-4806

Zwart G, Crump BC, Kamst-van Agterveld MP, Hagen F, Han S (2002) Typical freshwater bacteria: an analysis of available 16S rRNA gene sequences from plankton of lakes and rivers. Aquat Microb Ecol 28:141-155

Submitted: April 21, 2005; Accepted: September 9, 2005 Proofs received from author(s): January 9, 2006 